\title{
A case report of severe recurrent varicella in an ankylosing spondylitis patient treated with adalimumab - a new side effect after 15 years of usage
}

Tomislava Skuhala ${ }^{1,2^{*}}$ (B), Anita Atelj ${ }^{1}$, Jelena Prepolec ${ }^{3}$, Mahmoud Al-Mufleh ${ }^{4}$, Andrija Stanimirović ${ }^{5}$ and Dalibor Vukelić ${ }^{1,3}$

\begin{abstract}
Background: Tumor necrosis factor-a (TNF-a) antagonists, most of which are monoclonal antibodies, became a widespread treatment for autoimmune diseases such as rheumatoid arthritis, ankylosing spondylitis, inflammatory bowel diseases, psoriasis, psoriatic arthritis, hidradenitis suppurativa and uveitis. Their use is based on the blockage of TNF-a, which plays an important role in granulomas formation, development of phagosomes, activation and differentiation of macrophages, immune response against viral pathogens. The multiple adverse effects of TNF- $a$ inhibition have been identified, including a two-to four-fold increased risk of active tuberculosis and other granulomatous conditions and an increased occurrence of some other serious bacterial, fungal and certain viral infections.
\end{abstract}

Case presentation: A 34-year-old male patient with disseminated varicella and pneumonitis was admitted to our hospital. The diagnosis of varicella was established serologically by enzyme immunoassay (EIA) and by polymerase chain reaction confirmation of the virus in vesicular fluid. The patient has been receiving adalimumab and methotrexate for the last 3 years due to ankylosing spondylitis and was seropositive to varicella zoster virus prior to the introduction of TNF-a antagonists. Acyclovir was administered for 10 days with the resolution of clinical illness and radiological signs of pneumonitis.

Conclusion: Due to the use of biological agents, particularly TNF-a inhibitors, as a well-established therapy for some autoimmune diseases, new potential adverse events can be expected in the future and we wanted to point out one of them. To our knowledge this is the first case of recurrent disseminated varicella in a patient taking TNF-a antagonists.

Keywords: Adalimumab, Varicella virus, Severe recurrent infection, Pneumonia, Case report

\section{Background}

Tumor necrosis factor- $\alpha$ (TNF- $\alpha$ ) antagonists, most of which are monoclonal antibodies (infliximab, golimumab, adalimumab), became a widespread treatment for autoimmune diseases such as rheumatoid arthritis, ankylosing spondylitis, inflammatory bowel diseases, psoriasis, psoriatic arthritis, hidradenitis suppurativa and uveitis. Their

* Correspondence: tomislava_skuhala@yahoo.com

1University Hospital for Infectious Diseases "Dr. Fran Mihaljević", Mirogojska 8, 10000 Zagreb, Croatia

${ }^{2}$ School of Dental Medicine, University of Zagreb, Zagreb, Croatia

Full list of author information is available at the end of the article use is based on the blockage of TNF- $\alpha$, which plays an important role in granulomas formation, development of phagosomes, activation and differentiation of macrophages, immune response against viral pathogens [1-3]. Adalimumab is a recombinant human immunoglobulin (Ig) G monoclonal antibody specific for human TNF- $\alpha$ which causes modulation of the inflammatory response activated by this cytokine.

However, multiple adverse effects of TNF- $\alpha$ inhibition have been identified, including a two-to four-fold increased risk of active tuberculosis and other granulomatous

(c) The Author(s). 2019 Open Access This article is distributed under the terms of the Creative Commons Attribution 4.0 International License (http://creativecommons.org/licenses/by/4.0/), which permits unrestricted use, distribution, and 


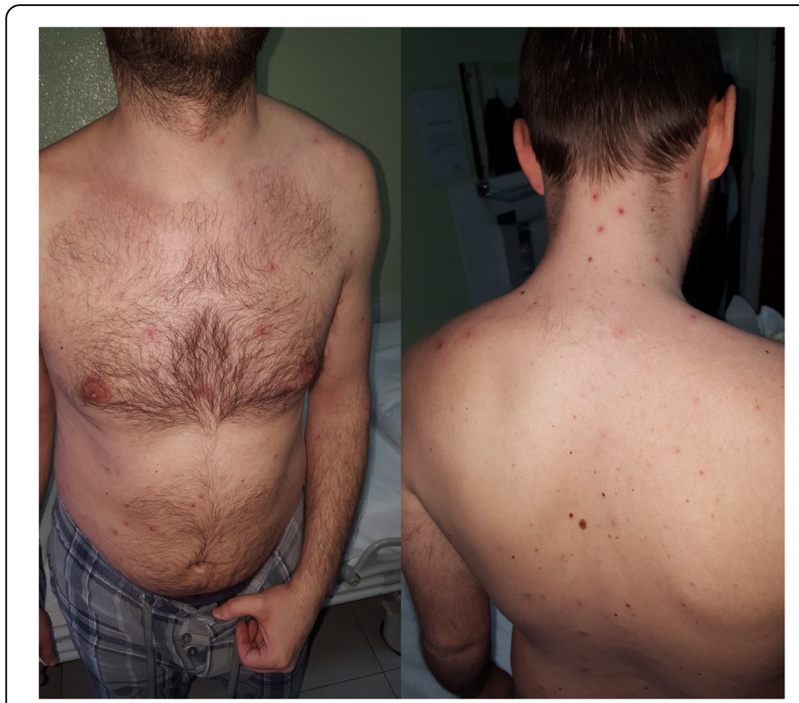

Fig. 1 Papular and vesicular rash on the neck and trunk

conditions and an increased occurrence of some other serious bacterial, fungal and certain viral infections [4-6].

\section{Case presentation}

We report a case of a 34-year-old patient with a medical history of fever, malaise, cough, and generalized vesicular rash that started 1 day before admission. 14 days prior to disease onset, the patient's son developed chickenpox. The patient had a history of ankylosing spondylitis and has been treated with adalimumab $40 \mathrm{mg}$ subcutaneously biweekly in addition to methotrexate $10 \mathrm{mg}$ per week for the last 2 years. He had had chickenpox at the age of 5 , and positive IgG antibodies (titre 24; positive $>11$ ) to varicella-zoster virus (VZV) using EIA in 2014, prior to the initiation of adalimumab treatment.
On admission to the hospital, physical examination revealed a subfebrile $\left(37.3^{\circ} \mathrm{C}\right)$ patient with papular and vesicular rash over the entire body (Fig. 1). Laboratory test results showed: erythrocyte sedimentation rate $17 \mathrm{~mm} / 1 \mathrm{st}$ hour, C-reactive protein $17,7 \mathrm{mg} / \mathrm{l}$, white blood cell count 4,8 $\times 109 / 1$ with $56 \%$ neutrophils and $25 \%$ lymphocytes in differential count, elevated fibrinogen $(3,1 \mathrm{~g} / \mathrm{l})$. Other standard parameters such as haemoglobin concentration, platelet count, glucose concentration, plasma ion levels, renal and liver functional tests, coagulation tests and urinalysis were all normal. A chest radiograph showed diffuse bilateral nodular infiltrates (Fig. 2a). Recurrent varicella infection was suspected and intravenous acyclovir was administered $(10 \mathrm{mg} / \mathrm{kg}$ every $8 \mathrm{~h})$. A Tzanck smear revealed multinucleated giant cells and VZV deoxyribonucleic acid (DNA) was detected in vesicular fluid by polymerase chain reaction. Serological testing for VZV using EIA was performed on the third day of illness and IgM (titre 15; positive > 11), IgG (titre 36; positive > 11) and IgA (titre 12; positive >11) antibodies to VZV were detected. Based on the clinical and laboratory findings, the diagnosis of recurrent varicella with pneumonia was established. The patient was treated with intravenous acyclovir (750 mg every $8 \mathrm{~h}$ ) for 7 days, followed by oral acyclovir ( $800 \mathrm{mg}$ five times daily) for 3 more days. He remained febrile for 3 days with rapid resolution of the rash and radiological resolution of pulmonary infiltrates (Fig. 2b).

\section{Discussion and conclusions}

Patients receiving TNF- $\alpha$ antagonists therapy remain at a selectively increased risk for more severe primary varicella infections compared with the general population, with the estimated incidence rate of hospitalization due to chickenpox of 26 cases per 100,000 (95\% CI 10-69) compared with the expected rate of 1.9 (95\% CI 1.8-2.0)

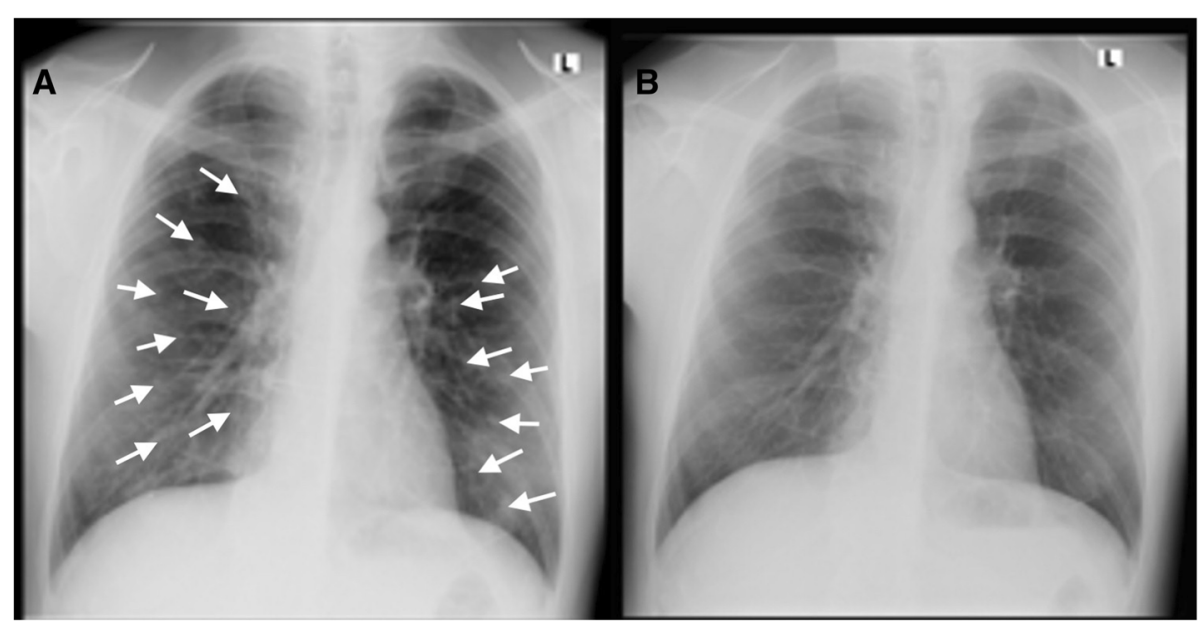

Fig. 2 a Chest radiograph on the day of admission revealed diffuse nodular infiltrates. b Radiological resolution of pulmonary infiltrates after 10 days of acyclovir therapy 
in the general population [7]. Contradictory results have been published reporting the association between TNF- $\alpha$ therapy and herpes zoster.

Several large population-based studies have been conducted, with those performed in the United States not finding an increased risk with TNF- $\alpha$ inhibitors, contrary to those in Europe generally showing an increased risk $[4,8,9]$. There were multiple reports of severe and disseminated herpes zoster and primary varicella associated with TNF- $\alpha$ therapy (infliximab and adalimumab) [1, 10-15]. In contrast, recurrent varicella infections during TNF- $\alpha$ therapy were rarely reported, with only one case featuring few clinical symptoms (no dissemination and resolution of skin lesions without antiviral treatment) in the course of etanercept administration [16]. VZV causes two clinically distinct diseases - primary infection resulting in varicella and herpes zoster resulting from the reactivation of latent VZV that gained access to sensory ganglia during varicella [17]. It is traditionally considered that VZV infection provides lifelong immunity but recurrent infection (also referred to as reinfection or second varicella infection) with VZV occur more commonly than previously thought $[18,19]$. In an active surveillance initiative in California, the percentage of patients diagnosed with varicella who reported previous varicella infections ranged from 4.5 to $13.3 \%$ [18]. VZV recurrent infection can occur even in immunocompetent patients, and our patient was predisposed to infection by his rheumatologic disease and immunosuppressive therapy. Patients with a history of underlying malignancy, steroid use or immunosuppressive therapy, HIV infection, or solid organ transplantation are susceptible for disseminated varicella due to impaired cellular immunity. Clinical manifestations in the immunosuppressed host can include atypical and severe manifestations such as development of crops of vesicles over weeks, large and haemorrhagic skin lesions, pneumonia, or widespread disease with disseminated intravascular coagulation $[17,20]$. The antiviral therapy is recommended for immunocompromised hosts who present with varicella because they are at risk for developing disseminated varicella, as our patient has been, and can also experience more frequent severe morbidity and higher mortality rates compared with immunocompetent hosts $[20,21]$. Early clinical recognition of VZV infection in high risk patients, such are all immunocompromised patients, as well as laboratory detection and confirmation of VZV require early aggressive antiviral treatment leading to favourable clinical outcome $[7,17,20]$.

Due to the use of biological agents, particularly TNF- $\alpha$ inhibitors, as a well-established therapy for some autoimmune diseases, new potential adverse events can be expected in the future and we wanted to point out one of them. To the best of our knowledge, this is the first case of confirmed recurrent varicella with disseminated disease and pneumonia in a patient receiving adalimumab since this drug has been approved for use in 2002 in the United States and 2003 in the European Union [22, 23].

\begin{abstract}
Abbreviations
DNA: Deoxyribonucleic acid; EIA: Enzyme immunoassay test;

Ig: Immunoglobulin; TNF-a: tumor necrosis factor-a; VZV: Varicella-zoster virus

Acknowledgements

Not applicable.

Funding

None.

Availability of data and materials

Not applicable.

Authors' contributions

$\mathrm{TS}, \mathrm{AA}, \mathrm{MA}, \mathrm{JP}, \mathrm{AS}$ and $\mathrm{DV}$ were involved in the clinical management of this case. TS drafted the original manuscript under the guidance of DV and AS. All authors read and approved the final manuscript.
\end{abstract}

Ethics approval and consent to participate

Not applicable.

\section{Consent for publication}

Written informed consent was obtained from the patient for publication of this case report and any accompanying images. A copy of the written consent is available for review by the Editor of this journal, upon request.

Competing interests

The authors declare that they have no competing interests.

\section{Publisher's Note}

Springer Nature remains neutral with regard to jurisdictional claims in published maps and institutional affiliations.

\section{Author details}

'University Hospital for Infectious Diseases "Dr. Fran Mihaljević", Mirogojska 8, 10000 Zagreb, Croatia. ${ }^{2}$ School of Dental Medicine, University of Zagreb, Zagreb, Croatia. ${ }^{3}$ School of Medicine, University of Zagreb, Zagreb, Croatia. ${ }^{4}$ Resident in Infectious Diseases, County Hospital Čakovec, Čakovec, Croatia. ${ }^{5}$ Department of Clinical Medicine, University of Applied Health Sciences, Zagreb, Croatia.

Received: 12 November 2018 Accepted: 30 January 2019

Published online: 07 February 2019

\section{References}

1. Baek W, Lee SG, Kim YS, Kim JH, Jun JB, Kim HY. Fatal varicella-Zoster virus vasculopathy associated with adalimumab therapy. Arch Neurol. 2012;69:1193-6.

2. Koo S, Marty FM, Baden LR. Infectious complications associated with immunomodulating biologic agents. Infect Dis Clin N Am. 2010;24:285.

3. Ali T, Kaitha S, Mahmood S, Ftesi A, Stone J, Bronze MS. Clinical use of anti-TNF therapy and increased risk of infections. Drug Healthc Patient Saf. 2013:5:79e99.

4. Baddley JW, Cantini F, Goletti D, Gómez-Reino JJ, Mylonakis E, San-Juan R, et al. ESCMID study Group for Infections in compromised hosts (ESGICH) consensus document on the safety of targeted and biological therapies: an infectious diseases perspective (soluble immune effector molecules [1]: anti-tumor necrosis factor-a agents). Clin Microbiol Infect. 2018;24:S10-20.

5. Rychly DJ, DiPiro JT. Infections associated with tumor necrosis factor-alpha antagonists. Pharmacotherapy. 2005;25:1181-92.

6. Downey C. Serious infection during etanercept, infliximab and adalimumab therapy for rheumatoid arthritis: a literature review. Int J Rheum Dis. 2016;19:536-50. 
7. García-Doval I, Pérez-Zafrilla B, Descalzo MA, Roselló R, Hernández MV Gómez-Reino JJ, et al. Incidence and risk of hospitalisation due to shingles and chickenpox in patients with rheumatic diseases treated with TNF antagonists. Ann Rheum Dis. 2010;69:1751-5.

8. Strangfeld A, Listing J, Herzer P, Liebhaber A, Rockwitz K, Richter C, et al. Risk of herpes zoster in patients with rheumatoid arthritis treated with anti-TNF-alpha agents. JAMA. 2009;301:737-44.

9. Tran CT, Ducancelle A, Masson C, Lunel-Fabiani F. Herpes zoster: risk and prevention during immunomodulating therapy. Joint Bone Spine. 2017:84:21-7.

10. Leung VS, Nguyen MT, Bush TM. Disseminated primary varicella after initiation of infliximab for Crohn's disease. Am J Gastroenterol. 2004:99:2503-4.

11. Vonkeman $\mathrm{H}$, ten Napel $\mathrm{C}$, Rasker $\mathrm{H}$, van de Laar M. Disseminated primary varicella infection during infliximab treatment. J Rheumatol. 2004:31:2517-8.

12. Elwir SM, Shaffer CC, Arvan SW, Kuperman EF. Disseminated varicella zoster virus infection with encephalitis in a UC patient receiving infliximab. Gastroenterol Hepatol (NY). 2013;9:54-6.

13. Miyagi T, Yamaguchi S, Yamamoto Y, Ohira A, Yasumura R, Nakasone N, et al. Varicella zoster virus encephalopathy in a patient with psoriatic arthritis treated with anti-TNFa agents. Eur J Dermatol. 2014;24:398-9.

14. Buccoliero G, Lonero G, Romanelli C, Loperfido P, Resta F. Varicella zoster virus encephalitis during treatment with anti-tumor necrosis factor-alpha agent in a psoriatic arthritis patient. New Microbiol. 2010;33:271-4.

15. Lee DH, Kim HS, Song YW, Cho KH. Development of varicella during adalimumab therapy. J Eur Acad Dermatol Venereol. 2007:21:687-8.

16. Becart $\mathrm{S}$, Segaert $\mathrm{S}$. Recurrent varicella in an adult psoriasis patient treated with etanercept. Dermatology. 2008;217:260-1.

17. Heininger U, Seward JF. Varicella. Lancet. 2006;368:1365-76.

18. Hall S, Maupin T, Seward J, Jumaan AO, Peterson C, Goldman G, et al. Second varicella infections: are they more common than previously thought? Pediatrics. 2002;109:1068-73.

19. Johnson JA, Bloch KC, Dang BN. Varicella reinfection in a seropositive physician following occupational exposure to localized zoster. Clin Infect Dis. 2011:52:907-9.

20. Straus SE, Ostrove JM, Inchauspé G, Felser JM, Freifeld A, Croen KD, et al. $\mathrm{NIH}$ conference. Varicella-zoster virus infections. Biology, natural history, treatment, and prevention. Ann Intern Med. 1988;108:221.

21. WHO. Varicella and herpes zoster vaccines. WHO Position Paper. 2014;89:265-88

22. European Medicines Agency. Humira. Summary of product characteristics. 2015. Available from: http://www.ema.europa.eu/docs/en_GB/document_ library/EPAR___Product_Information/human/000481/WC500050870.pdf. Accessed 20 Oct 2018

23. US Food and Drug Administration: Humira. Highlights of prescribing information 2008. Available from: https://www.accessdata.fda.gov/ drugsatfda_docs/label/2008/125057s114|bl.pdf. Accessed 20 Oct 2018.

Ready to submit your research? Choose BMC and benefit from:

- fast, convenient online submission

- thorough peer review by experienced researchers in your field

- rapid publication on acceptance

- support for research data, including large and complex data types

- gold Open Access which fosters wider collaboration and increased citations

- maximum visibility for your research: over $100 \mathrm{M}$ website views per year

At $\mathrm{BMC}$, research is always in progress.

Learn more biomedcentral.com/submissions 